\title{
Menggagas Titik Ekuilibrium Sistem Pemilihan dengan Sistem Pemerintahan
}

\author{
Rudhi Achsoni \\ Fakultas Hukum Universitas Muhammadiyah Maluku Utara, email: rudhiachsoni@gmail.com
}

\begin{abstract}
Abstrac
The electoral system is a choice of ways to elect the President and Vice President, DPR, DPD, $D P R D$, as well as the election of regional heads and deputy regional heads, while the government system is a model choice for implementing executive government in relation to the legislative function. Discussing the electoral system with the government system are two different things, but it cannot be separated, because in practice the election system model often occurs that is not compatible with the choice of government system, the State of Indonesia has chosen the presidential system as a government system, but the election system model is carried out Apart from the executive and legislative branches, such conditions cause instability in the government and in some cases the executive is not infrequently dictated by the legislature.

The model of the electoral system scheme and the central government system has been straightened through the decision of the Constitutional Court Number 14 / PUU-XI / 2013 which was then practiced in the 2019 elections, but it is unfortunate that the scheme of adjusting the election system and the government system was not applied at the regional level, where the regional head election and legislative members in the regions are carried out separately, such conditions lead to a number of problems such as instability of regional government, erosion of regional strategic issues in the campaign, short-term coalitions, rulers minus control of the electorate, flourishing attitudes of politicians opportunism in the regions. In order to find solutions to these problems, it becomes important to find the equilibrium point between the electoral system and the choice of presidential system by redesigning the national and regional level election models, it is hoped that through this idea the stability of government in the region will be maintained, important issues the region becomes a concern, the coalition in the region is not pragmatic, the ruler gets control from the voters, and the opportunism of politicians in the region will be minimized
\end{abstract}

Keywords: Election System; Government system; Equilibrium Point

\section{PENDAHULUAN}

Sistem pemilihan merupakan satu pilihan cara untuk memilih Presiden dan Wakil Presiden, Dewan Perwakilan Rakyat (DPR), Dewan Perwakilan Daerah (DPD), Dewan Perwakilan Rakyat Daerah (DPRD), serta pemilihan kepala daerah dan wakil kepala daerah, sementara sistem pemerintahan merupakan pilihan model penyelenggaraan pemerintahan eksekutif dalam hubungannya dengan fungsi legislatif. Negara Indonesia sudah menentukan pilihan sistem pemerintahan presidensial dalam konstitusinya, sehingga pilihan tersebut memiliki konsekuensi dengan sistem pemilihan umum yang akan dipilih. Model pemilihan umum angota DPR, DPD dan DPRD yang tidak serentak dengan pemilihan Presiden dan Wakil Presiden telah terbukti menyebabkan 
pemerintahan terbelah (devided government), karena didasari fenomena Presiden dan Wakil Presiden terpilih tidak memiliki dukungan yang cukup di parlemen, sehingga Mahkamah Konstitusi (MK) dalam putusan nomor 14/PUU-XI/2013 meluruskan dengan berpandangan bahwa prinsipnya pemilihan Presiden dan Wakil Presiden dengan pemilihan lembaga perwakilan pusat yang tidak dilakukan secara serentak, tidak sejalan dengan semangat untuk memperkuat sistem presidensial yang hendak dibangun berdasar konstitusi, lebih lanjut MK menegaskan bahwa mekanisme saling imbang dan saling mengawasi (checks and balances) antar Pemerintah dan DPR tidak berjalan dengan baik, serta koalisi yang terbangun adalah koalisi taktis dan pragmatis ${ }^{1}$. Putusan nomor 14/PUU-XI/2013 ini menurut Saldi Isra tergolong berani, karena MK dalam putusan tersebut telah melakukan koreksi total atas kesalahan sistemik terhadap pemaknaan pasal 22E ayat (1) dan (2) UUD $1945^{2}$. Mahkamah Konstitusi tergolong produktif dalam mengoreksi UU yang terkait dengan pemilu, Very Junaidi menyampaikan bahwa hingga April 2019 MK telah mengeluarkan putusan PUU terkait pemilu sebanyak 162 (seratus enam puluh dua), dan dari jumlah tersebut, 63 (enam puluh tiga) putusan berbunyi tak dapat diterima dan 54 (lima puluh empat) putusan dengan status ditolak, selain itu putusan yang dikabul oleh MK cukup banyak yakni 31 (tiga puluh satu) dengan 21 (dua puluh satu) putusan dikabulkan sebagian, serta terdapat 10 (sepuluh) putusan yang dikabulkan seluruhnya. Kemudian hanya 1 (satu) putusan yang dinyatakan gugur dan 13 (tiga belas) ketetapan ${ }^{3}$.

Berdasar pertimbangan dalam putusan nomor 14/PUU-XI/2013, MK akhirnya mengabulkan untuk pemilihan Presiden dan Wakil Presiden serta pemilihan DPR, DPD dan DPRD dilakukan secara serentak pada tahun 2019. Mengamati argumentasi yang bangun oleh MK, maka penulis berpandangan bahwa sudah seyogyanya model pemilihan serentak di tingkat pusat tersebut diturunkan dan dipraktikkan ditingkat daerah, karena praktik dilapangan menunjukkan bahwa model pemilihan kepala daerah yang tidak serentak dengan pemilihan parlemen di daerah telah menimbulkan persoalan.

Pemerintahan daerah adalah penyelenggaraan urusan pemerintahan oleh pemerintah daerah dan dewan perwakilan rakyat daerah ${ }^{4}$, sementara penyelenggara pemerintahan Provinsi dan Kabupaten/Kota terdiri atas Kepala Daerah dan DPRD dibantu oleh perangkat daerah ${ }^{5}$, sehingga berjalannya roda pemerintahan daerah akan sangat dipengaruhi oleh dua kekuatan besar, yaitu pertama Gubernur Bupati/walikota (selaku eksekutif daerah) dan kedua adalah DPRD Provinsi dan Kabupaten/Kota (selaku legislatif daerah). Dalam praktik dilapangan sering kali 2 (dua) kekuatan besar ini tidak selalu sejalan dalam menahkodai kapal besar yang namanya pemerintahan daerah. Oleh karenanya sinergitas 2 (dua) kekuatan besar tersebut sangat diperlukan dalam mengantarkan kapal besar sampai kepelabuhan yang dinginkan oleh rakyat selaku penumpang kapal besar tersebut.

Menurut hemat penulis model pemilihan kepala daerah dan legislatif daerah yang tidak dilakukan secara serentak menumbulkan beberapa persoalan, seperti ketidakharmonisan hubungan eksekutif dan legislatif di daerah, tergerusnya isu-isu strategis

\footnotetext{
${ }^{1}$ Putusan Mahkamah Konstitusi Nomor 14/PUU-XI/2013, hlm. 81.

${ }^{2}$ Saldi Isra,(2017), Pemilu dan Pemulihan Daulat Rakyat, Jakarta, Themis Publishing, hlm 5.

${ }^{3}$ Very Junaidi dkk,(2019), Membaca 16 tahun Mahkamah Konstitusi data uji materi undangundang terhadap UUD 1945 (2003-2019), Jakarta, Yayasan Konstitusi Demokrasi Inisiatif, hlm. 203.

${ }^{4}$ Pasal 1 angka 2 Undang-Undang Nomor 23 tahun 2014 tentang Pemerintahan Daerah.

${ }^{5}$ Ibid., Pasal 57...
} 
daerah dalam kampanye, koalisi yang terbangaun di daerah bersifat pragmatis, penguasa yang minus kontrol dari pemilih, serta tumbuh suburnya opportunisme politisi di daerah, berdasarkan hal tersebut tulisan ini hendak menggagas titik ekuilibrium antara sistem pemilihan dengan pilihan sistem presidensial ditingkat daerah, berharap melalui gagasan tersebut maka roda pemerintahan daerah akan mampu berjalan dengan baik sehingga kesejahteraan masyarakat sebagai arah yang hendak dituju juga dapat terwujud.

\section{METODE PENELITIAN}

Penelitian ini menggunakan tipe penelitian hukum ${ }^{6}$ dengan menggunakan pendekatan konseptual dan pendekatan perundang-undangan. ${ }^{7}$ Data yang digunakan merupakan data sekunder meliputi bahan hukum primer berupa putusan pengadilan dan bahan hukum sekunder yang terdiri dari buku teks, artikel pada jurnal ilmiah dan laporan hasil penelitian terdahulu. Bahan-bahan hukum tersebut kemudian dianalisis secara kualitatif dan disajikan secara deskriptif analitis sehingga dapat menjawab permasalahan dalam kajian penelitian ini.

\section{ANALISIS}

\section{Sistem Pemilihan}

Pemilihan umum (Pemilu) adalah bentuk atau mekanisme sistem pemerintahan suatu negara sebagai upaya mewujudkan kedaulatan rakyat, dan secara filsafati Teguh Prasetyo mengartikan pemilu sebagai suatu sistem berfikir, termasuk sistem diskursus yang terbangun diatas suatu fondasi tertentu, ketat dan terkontrol atau diawasi ${ }^{8}$. Pada tataran yuridis pemilu diartikan sebagai sarana kedaulatan rakyat untuk memilih anggota DPR, DPD, Presiden dan Wakil Presiden, dan untuk memilih anggota DPRD yang dilaksanakan secara langsung, umum, bebas, rahasia, jujur, dan adil dalam Negara kesatuan republik Indonesia berdasarkan pancasila dan Undang-Undang Dasar Negara Republik Indonesia Tahun $1945^{9}$. Pada sisi lain kata Pemilihan didefenisikan sebagai pelaksanaan kedaulatan rakyat di wilayah Provinsi dan Kabupaten/Kota untuk memilih Gubernur dan Wakil Gubernur, Bupati dan Wakil Bupati, serta Walikota dan Wakil Walikota secara langsung dan demokratis. ${ }^{10}$

Merujuk pada bunyi Pasal di atas maka terdapat perbedaan antara Pemilu dengan Pemilihan, dan perbedaan ini diperkuat putusan MK yang pada prinsipnya memberi tafsir beda antara kata pemilu dan pemilihan, dan finally MK berpandangan bahwa yang menjadi kewenangan MK dalam memutus perselisihan hasil Pemilu, adalah pemilu DPR, DPD, Presiden dan Wakil Presiden, dan DPRD ${ }^{11}$. Kandungan dalam Pemilu menurut Saldi Isra bila merujuk pada sejarahnya, salah satunya adalah dalam Konstitusi Republik Indonesia serikat (RIS) maka terkandung 7 (tujuh) asas penyelenggaraan

6 Soerjono Soekanto\&Sri Mamudji,(2011),Penelitian Hukum Normatif,Jakarta, Rajawali Pers,hlm. 14.

${ }^{7}$ PM. Marzuki, (2010), Penelitian Hukum, Jakarta, Kencana Prenada Media Group, hlm. 96.

${ }^{8}$ Teguh Prasetyo, (2018), Filsafat Pemilu, Bandung, Penerbit Nusa Media, hlm. 15.

${ }^{9}$ Pasal 1 angka 1 Undang-Undang Nomor 7 Tahun 2017 tentang Pemilihan Umum.

${ }^{10}$ Pasal 1 angka 1 Undang Nomor 8 tahun 2015 tentang Perubahan atas Undang-Undang Nomor 1 Tahun 2015 tentang Penetapan Peraturan Pemerintah Pengganti Undang-Undang Nomor 1 Tahun 2014 tentang Pemilihan Gubernur, Bupati, dan Walikota menjadi Undang-Undang.

${ }^{11}$ Pasal 22E ayat (2) Undang-Undang Dasar Negara RI Tahun 1945. 
pemilu, yaitu: asas berkala, jujur menjamin hak pilih, umum, berkesemaan, rahasia, dan bebas. ${ }^{12}$

Penjelasan lebih detail dalam konstitusi RIS menyangkut 7 (tujuh) asas tersebut tidak ditemukan, namun dalam rangka memastikan original inten pembentuk UndangUndang Dasar Negara RI Tahun 1945 tentang kata dipilih secara demokratis dalam Pasal 18 ayat (4) UUD Negara RI Tahun 1945, dengan kata pemilihan umum dalam pasal 22 e ayat (2) UUD Negara RI Tahun 1945, maka penulis berpandangan bahwa pasal 18 ayat (4) lahir dalam kurun waktu tahun 2000 yaitu pada saat amandemen ke 2 (dua), dimana waktu itu belum terjadi kesepakatan perihal apakah kepala daerah hendak dipilih secara langsung atau tidak langsung, sehingga disepakati bahwa nanti model pemilihan kepala daerah akan menyesuaikan dengan model pemilihan Presiden dan Wakil Presiden. Selanjutnya dalam perdebatan amandemen ke 3 (tiga) tahun 2001, disepakati bahwa anggota DPR, DPD, Presiden dan Wakil Presiden Presiden dan DPRD dipilih secara langsung ${ }^{13}$. menurut hemat penulis kesepakatan dipilih secara langsng tersebut tidak terlepas dari Pasal 1 ayat (2) yang menyatakan bahwa kedaulatan berada ditangan rakyat dan dilaksanakan menurut Undang-Undang Dasar, berdasar pada kesepakatan dalam pasal 22E ayat (2) UUD Negara RI Tahun 1945. Berdasar alur fikir demikian maka sudah seyogyanya model pemilihan kepala daerah juga dipilih secara langsung, dan argumentasi yang membedakan kata pemilu dan pemilihan menjadi berat untuk dibenarkan, terlebih ketika terdapat pembenaran dengan menggunakan argumentasi bahwa kata pemilu masuk dalam rezim pasal 22E UUD Negara RI Tahun 1945, sementara kata pemilihan kepala daerah masuk dalam rezim pemerintahan daerah sebagaimana diatur dalam pasal 18 UUD Negara RI Tahun 1945, argument tersebut semakin terlihat dipaksakan karena pada faktanya dalam Pasal 18 UUD Negara RI Tahun 1945 terdapat diksi DPRD dimana diksi DPRD juga muncul dalam Pasal $22 \mathrm{E}$ UUD Negara RI Tahun 1945. Pada sisi yang lain juga bila dicermati dalam pemilihan kepala daerah mengadopsi semua asas dalam pemilu, serta penyelenggara pemilu pada pemilihan kepala daerah dengan penyelengara pemilu pada pemilu Presiden dan DPR, DPD dan DPRD adalah penyelenggara pemilu yang sama, dengan bentangan argumentasi demikian maka tidak cukup kuat alasan yang mengatakan pemilihan kepala daerah bukan masuk sebagai pemilihan umum sebagaimana dimaksud dalam Pasal 22 E UUD Negara RI Tahun 1945.

Peristiwa tumpang tindihnya proses amandemen konstitusi perihal pemilihan langsung dan tidak langsung dalam Pasal 18 Undang-Undang Dasar Negara RI Tahun 1945, dengan Pasal 22 E Undang-Undang Dasar Negara RI Tahun 1945 bisa difahami karena proses amandemen memang tidak dipersiapkan dengan baik oleh para elit yang berkuasa saat itu, hal tersebut senada dengan pandangan Pan Muhammad Faiz yang mengakui bahwa amandemen konstitusi di Indonesia memang telah membawa hal positif terhadap sistem konstitusi dan demokrasi Indonesia, namun Pan Muhammad Faiz juga mengakui bahwa terdapat beberapa kelemahan terkait proses dan tata cara amandemen konstitusi periode 1999 - 2002, mulai soal sistematika UUD 1945 yang tidak teratur, proses amandemen konstitusi sangat dipengaruhi oleh identitas dan

${ }^{12}$ Saldi Isra, Khairul Fahmi, (2019), Pemilihan Umum Demokratis, Depok, Rajawali Press, hlm 13.

\footnotetext{
${ }^{13}$ Pasal 22E ayat (2) UUD Negara RI Tahun 1945.
} 
kepentingan partai-partai politik, sistem kamar parlemen yang tidak jelas, serta keabsurdan sistem pemerintahan ${ }^{14}$.

Pemilihan umum dilaksanakan secara periodik untuk memilih Presiden dan Wakil Presiden (Pilpres), dan juga pemilihan anggota DPR, DPD dan DPRD (Pileg). Dalam konstitusi dinyatakan bahwa Presiden dan Wakil Presiden memegang jabatan selama 5 (lima) tahun, dan sesudahnya dapat dipilih kembali dalam jabatan yang sama, hanya untuk satu kali masa jabatan ${ }^{15}$. Lebih detil lagi pada bab Khusus tentang Pemilu dinyatakan bahwa Pemilihan Umum dilaksanakan secara langsung, umum, bebas, rahasia, jujur, dan adil setiap lima tahun sekali ${ }^{16}$. Berangkat dari norma tersebut maka sistem pemilihan umum untuk memilih Presiden, DPR, DPD dan DPRD dilakukan secara periodik yaitu 5 (lima) tahun sekali.

Pemilihan Presidan dan Wakil Presiden secara langsung oleh rakyat pertama kali digelar adalah pada tahun 2004, kemudian berlanjut 2009, 2014, dan terakhir adalah tahun 2019. Pelaksanaan pemilihan Presiden dan Wakil Presiden dengan pelaksanaan pemilihan legislatif dilaksanakan tidak bersamaan, dimana pemilihan Presiden dan Wakil Presiden (Pilpres) dilakukan terlebih dahulu, setelahnya baru dilakukan pemilihan anggota DPR, DPD, dan DPRD (Pileg). Model sistem pemilihan tersebut dilakukan gugatan di Mahkamah Konstitusi oleh Effendi Gozali dengan beberapa argumentasi, beberapa diantaranya adalah, pemilihan Presiden dan Wakil Presiden dengan Pemilihan anggota DPR, DPD dan DPRD yang tidak serentakkan terjadi pemborosan anggaran negara yang luar biasa, kemudian argumentasi tentang hak warga negara untuk memilih secara cerdas dan efisien yang tidak terpenuhi, kemudian argumentasi original inten dalam risalah pembahasan amandemen UUD Negara RI Tahun 1945, serta yang paling menarik adalah argumentasi menyangkut pemilu serentak ditingkat pusat sebagai upaya menyelaraskan dengan pilihan sistem presidensial.

Berdasar pada gugatan tersebut Mahkamah Konstitusi memutuskan bahwa dalam rangka menimbang Pilpres dilaksanakan setelah Pileg, atau Pilpres dilakukan bersamaan dengan penyelenggaraan Pileg, maka MK mempertimbangkan 3 (tiga) isu utama, pertama yaitu kaitan antara sistem pemilihan dan pilihan sistem pemerintahan presidensial, kemudian efektivitas dan efisiensi penyelenggaraan pemilihan umum, serta hak warga negara untuk memilih secara cerdas. ${ }^{17}$

Berdasarkan pada gugatan tersebut, MK menjatuhkan putusan bahwa norma pelaksanaan Pilpres yang dilakukan setelah Pemilu anggota lembaga perwakilan telah nyata tidak sesuai dengan semangat yang dikandung oleh UUD 1945 dan tidak sesuai dengan makna pemilihan umum yang dimaksud oleh UUD 1945, khususnya dalam Pasal 22E ayat (1) UUD 1945, dan Pasal 22E ayat (2) UUD 1945, serta Pasal 1 ayat (2) UUD 1945. Selanjutnya dikarenakan tahapan penyelenggaraan pemilihan umum tahun 2014 telah dan sedang berjalan mendekati waktu pelaksanaan. sehingga apabila Pasal 3 ayat (5) UU 42/2008 dan ketentuan-ketentuan lain yang berkaitan dengan tata cara dan persyaratan pelaksanaan Pilpres yang akan diputuskan harus diberlakukan segera setelah diucapkan dalam sidang terbuka untuk umum maka tahapan pemilihan umum tahun

\footnotetext{
${ }^{14}$ Pan Muhammad Faiz, (2019),Amandemen Konstitusi Komparasi Negara Kesatuan dan Negara Federal, Depok, Rajawali Pers, hlm. 94.

${ }_{15}^{15}$ Pasal 7 Undang-Undang Dasar Negara RI Tahun 1945.

${ }^{16}$ Pasal 22E ayat (1) Undang-Undang Dasar Negara RI Tahun 1945.

${ }^{17}$ Putusan Mahkamah Konstitusi Nomor 14/PUU-XI/2013, hlm. 84.
} 
2014 yang saat itu sedang berjalan menjadi terganggu. Oleh karenanya Mahkamah berpandangan bahwa diperlukan waktu untuk menyiapkan budaya hukum dan kesadaran politik yang baik bagi warga masyarakat, maupun bagi partai politik untuk mempersiapkan diri, sehingga pemilu serentak Pilpres dan Pileg berlaku pada tahun 2019 dan pemilihan umum seterusnya. ${ }^{18}$

Dari frame berfikir MK dalam putusan tersebut, maka terdapat point yang penting dilakukan under line, yaitu menyangkut hubungan antara sistem pemilihan dengan pilihan sistem pemerintahan presidensial, dimana secara tidak langsung MK hendak mengatakan bahwa pemilihan Presiden dan Wakil Presiden yang dilakukan tidak bersamaan dengan pemilihan anggota DPR, DPD, dan DPRD akan menuai sejumlah persoalan, salah satu diantaranya adalah terwujud situasi dimana pasangan calon Presiden dan Wakil Presiden kerap menciptakan koalisi taktis yang bersifat pragmatis dengan partai-partai politik sehingga tidak melahirkan koalisi jangka panjang yang dapat melahirkan penyederhanaan partai politik secara alamiah. Dari fakta tersebut keinginan membangun sistem presidensial yang kokoh akan sulit terwujud.

\section{Sistem Pemerintahan}

Sistem pemerintahan yang jamak dipraktikkan secara global, paling tidak ada 3 (tiga) macam, pertama adalah sistem pemerintahan presidensial, kedua sistem pemerintahan parlementer, ketiga sistem pemerintahan campuran. ${ }^{19}$ Model praktik presidensial dapat ditemukan di negara Amerika Serikat, model sistem parlementer dapat ditemukan di negara Inggris, model sistem campuran dapat ditemukan di negara Perancis. Dalam sistem pemerintahan Presidensial Mahfud MD menyatakan bahwa terdapat beberapa prinsip utama yaitu kepala negara menjadi kepala pemerintahan, kemudian pemerintah tidak bertanggung-jawab kepada Parlemen, kemudian menteri-menteri diangkat dan bertanggung-jawab kepada Presiden serta kedudukan eksekutif dan legislatif sama-sama kuat $^{20}$. Jimly Asshidiqie berpandangan bahwa sejak sebelum kemerdekaan, para pemimpin bangsa Indonesia sudah mengidealkan sistem pemerintahan Presidensial, hal tersebut terkonfirmasi dalam perumusan UUD 1945 yang mengatur bahwa kekuasaan pemerintahan menurut UUD dipegang oleh seorang Presiden dengan dibantu oleh satu orang Wakil Presiden selama 5 (lima) tahun dan sesudahnya dapat dipilih dalam jabatan yang sama hanya untuk satu kali masa jabatan ${ }^{21}$.

Sistem pemerintahan Parlementer memiliki ciri yang berbeda, dimana jabatan kepala negara (head of state) dan kepala pemerintahan (head of government) itu dibedakan dan dipisahkan satu sama lain, meskipun kedua jabatan tersebut sama sama merupakan cabang kekuasaan eksekutif. ${ }^{22}$ Pada sistem parlementer kepala negara biasanya dipimpin oleh seorang raja atau ratu, Presiden, dan kepala pemerintahan dipimpin oleh seorang perdana menteri, ciri berikutnya Perdana Menteri dapat dijatuhkan oleh parlemen dengan adanya mosi tak percaya, kemudian menteri-menteri biasanya diambil dari badan legislatif, kemudian anggota kabinet secara kolektif maupun masing-masing

${ }^{18}$ Ibid., Putusan MK..,hlm .86.

19 Jimly Asshidiqie, (2007), Pokok Pokok Hukum Tata Negara Indonesia Paska Reformasi, Jakarta, PT. Buana Ilmu Populer, hlm. 311.

${ }_{20}$ Moh. Mahfud MD, (1993), Dasar dan Struktur Ketatanegaraan Indonesia, Yogyakarta, Universitas Islam Indonesia Press, hlm. 83.

21 Jimly Asshidiqie,(2015),Penguatan Pemerintahan dan Peradilan,Jakarta,SinarGrafika,hlm 57.

${ }^{22}$ Loc.cit.,Jimly Asshidiqie, Pokok Pokok...hlm. 311. 
menterinya bertanggung-jawab kepada parlemen, dan Parlemen dapat membubarkan kabinet, kemudian kedudukan anggota kabinet amat bergantung kepada parlemen, dan kabinet tidak akan bisa bekerja tanpa ada persetujuan dari parlemen.

Sistem pemerintahan campuran, atau biasa disebut hybrid system, merupakan sebuah sistem yang menggabungkan beberapa elemen sistem pemerintahan Presidensial dan Parlementer. Seperti peran kepala negara dijalankan oleh Presiden, sedangkan kepala pemerintahan dilakukan oleh perdana menteri yang sebenarnya menjadi ciri Parlementer, kemudian selaku kepala negara, presiden tidak hanya menjalankan tugastugas seremonial yang simbolik, hal itu karena Presiden dipilih dan bertanggung jawab kepada rakyat secara langsung. Berikutnya dalam hal pertanggung-jawaban hybrid sitem, Perdana Menteri selain bertanggung-jawab kepada Presiden, pun bertanggungjawab kepada parlemen.

Berdasarkan uraian diatas Negara Indonesia terkategori sebagai sebuah negara yang telah menentukan pilihan untuk menggunakan sistem Presidensial. Beberapa ciri penting bahwa sistem Pemerintahan Presidensial telah digunakan di Indonesia antara lain, Presiden memegang kekuasaan Pemerintahan menurut Undang-Undang Dasar ${ }^{23}$, kemudian Presiden dan Wakil Presiden dipilih oleh rakyat secara langsung ${ }^{24}$, berikutnya Presiden dan Wakil Presiden memegang masa jabatannya selama 5 (lima) tahun, dan sesudahnya dapat dipilih kembali dalam jabatan yang sama, hanya untuk satu kali masa jabatan. ${ }^{25}$ kemudian Presiden dan Wakil Presiden tidak bertanggung-jawab kepada parlemen melainkan langsung bertanggung-jawab kepada rakyat, dalam hubungannya dengan parlemen Presiden juga tidak tunduk kepada parlemen, dan dalam Undang Undang Dasar Negara RI Tahun 1945 tidak mengenal pembedaan fungsi kepala negara dan kepala pemerintahan keduanya menyatu dalam diri seorang Presiden.

\section{Sistem Pemilihan yang tidak Kompatibel dengan Sistem Pemerintahan}

\section{a. Hubungan sistem pemilihan dengan pilihan sistem Presidensial di pusat.}

Sistem Pemilihan dengan Pilihan sistem Presidensial memiliki prasyarat agar keduanya dapat saling mensuport satu sama lain. Dibandingkan dengan sistem parlementer, sistem kepartaian dalam sistem presidensial menjadi isu yang amat menarik karena anggota lembaga legislatif dan Presiden dipilih secara langsung oleh rakyat. Bila mayoritas anggota legislatif menentukan pilihan politik yang berbeda dengan Presiden, sering kali sistem presidensial terjebak dalam pemerintahan yang terbelah (divided government). Belum lagi persoalan dimana marak fakta dilapangan bahwa dukungan legislatif makin sulit didapat jika pemerintahan Presidensial dibangun dalam sistem multipartai.

Salah satu alasan kuat mengapa multipartai dan sistem pemerintahan presidensial sulit digabungkan karena Presiden dan anggota DPR terpilih sama-sama mendapat mandat dari rakyat, sehingga dalam pola hubungan tersebut terdapat pertanyaan mendasar perihal siapa yang paling memiliki legitimasi untuk mengatasnamakan rakyat. Adapun efek karena sama-sama mendapat mandat langsung rakyat, perbedaan partai mayoritas di legislatif dengan partai politik presiden sering berdampak pada ketegangan di antara keduanya. Misalnya, praktik di AS perbedaan partai politik mayoritas dikongres dengan partai politik presiden sering menimbulkan pemerintahan yang terbelah. Kalaupun

\footnotetext{
${ }^{23}$ Pasal ayat (1) Undang-Undang Dasar Negara RI Tahun 1945.

${ }^{24}$ Pasal 6a ayat (1) Undang-Undang Dasar Negara RI Tahun 1945.

${ }^{25}$ Pasal 7 Undang-Undang Dasar Negara RI Tahun 1945.
} 
terbentuk, koalisi dalam sistem presidensial, maka kekuatan koalisi relatif lebih rapuh dibandingkan dengan koalisi dalam sistem parlementer.

Membaca keterkaitan sistem pemerintahan presidensial yang ditanam dalam bingkai multi partai seperti dijelaskan diatas, maka putusan MK Nomor 14/PUU/-XI/2013 yang memerintahkan agar Pilpres dan Pileg tahun 2019 dilakukan secara serentak menemukan urgensinya, karena apabila Pilpres dan Pileg dilakukan secara terpisah maka akan terbuka lebar potensi terpilihnya Presiden dengan dukungan minoritas di parlemen. Argumentasi Presiden dengan dukungan minoritas tersebut terkonfirmasi dengan fakta bahwa Presiden Indonesia sejak berlangsungnya reformasi mengalami persoalan perihal dukungan di parlemen, misalnya Presiden Abdurrahman Wahid basis dukungan politik dari Partai kebangkitan bangsa (PKB) hanya sekitar $20 \%$, kemudian Presiden Megawati Sukarno Putri basis dukungan politik hanya sekitar $30 \%$, kemudian Presiden Susilo Bambang Yudhoyono basis politiknya sekitar 20\%, dan Presiden Jokowi periode pertama hanya $19 \%^{26}$. Berdasarkan fenomena tersebut maka salah satu semangat yang dibangun pada saat amandemen konstitusi dilakukan adalah memperkuat sistem presidensial ${ }^{27}$, apabila sang Presiden mendapat dukungan minoritas di parlemen maka akan potensi terjadi pemerintahan yang terbelah.

Pelaksanaan Pemilihan Presiden dan Wakil Presiden setelah Pemilu anggota lembaga perwakilan akan memperlemah sistem presidensial yang hendak dibangun berdasarkan konstitusi. Karena sang Presiden kerap menciptakan koalisi taktis yang bersifat pragmatis. Berdasarkan pengalaman praktik ketatanegaraan sebagaimana telah diuraikan diatas, model pelaksanaan pemilihan Presiden setelah pemilu anggota lembaga perwakilan tidak memberi penguatan atas sistem pemerintahan yang dikehendaki oleh konstitusi.

\section{b. Problematika sistem pemilihan kepala daerah dengan pemilihan DPRD tidak serentak ditengah upaya memperkuat sistem pemerintahan daerah}

Upaya memperkuat sistem Presidensial pada tingkat pusat sudah dilakukan dengan jalan melaksanakan pemilihan secara serentak antara pemilihan legislatif dan pemilihan Presiden dan Wakil Presiden pada tahun 2019, dengan harapan agar warga negara yang memilih calon Presiden dapat pula menjatuhkan pilihan partai yang mendukung calon Presiden tersebut dalam Pilegnya, dan apabila situasi tersebut terwujud maka bangunan sistem presidensial yang dipilih akan lebih kokoh, karena partai pemenang dalam pemilihan lembaga perwakilan besar kemungkinan adalah partai yang mencalonkan Presiden dan Wakil Presiden terpilih. Hipotesa tersebut terkonfirmasi dalam Pemilihan Presiden dan Wakil Presiden tahun 2019, dimana Joko Widodo dengan Makruf Amin sebagai pasangan calon Presiden dan Wakil Presiden terpilih dicalonkan oleh Parati Demokrasi Indonesia Perjuangan (PDIP), dimana PDIP merupakan Partai Pemenang dalam pemilihan lembaga Perwakilan di pusat. Sehingga berdasar hasil pemilu tersebut maka stabilitas pemerintahan akan relatif terjaga, kemudian Presiden Jokowi pada periode kedua bisa lebih konsentrasi untuk merealisasikan janji kampanyenya, serta

\footnotetext{
${ }^{26}$ Samsudin Haris, Peneliti dari Lembaga Ilmu Pengetahuan Indonesia (LIPI), Materi disampaikan dalam rapat dengar pendapat umum dengan panitia khusus (Pansus) Rancangan Undang-Undang tentang Penyelenggaraan Pemilu, masa persidangan III, tertanggal 18 Januari 2017, hlm. 145.

${ }^{27}$ Denny Indrayana, (2009),Amandemen UUD 1945 Antara Mitos dan Pembongkaran, Bandung, Mizan, hlm. 275.
} 
dengan komposisi dukungan mayoritas diparlemen seperti sekarang maka kecil kemungkinan Presiden didikte oleh partai oposisi di parlemen.

Fakta pemilihan Presiden dan Wakil Presiden serta Pemilihan lembaga perwakilan yang dilakukan secara serentak pada tingkat pusat ini sangat disayangkan, karena tidak diterapkan pada tingkat daerah, penulis melihat bahwa model sistem pemilihan kepala daerah yang tidak bersamaan dengan pemilihan anggota Dewan Perwakilan Rakyat Daerah menimbulkan beberapa persoalan, berikut adalah beberapa diantaranya:

\section{1) Instabilitas Pemerintahan Daerah}

Pemerintahan Daerah terdiri dari kepala daerah dan dewan perwakilan rakyat daerah, selanjutnya merujuk pada desain konstitusi, maka Negara kesatuan republik Indonsia (NKRI) terbagi atas Provinsi, Provinsi terbagi atas Kabupaten/Kota dimana setiap Provinsi dan Kabupaten/Kota mempunyai pemerintah daerah menurut asas otonomi dan pembantuan $^{28}$. Pemerintah Provinsi dan Kabupaten/Kota memiliki DPRD Provinsi dan kabupaten/kota yang dipilih melalui pemilu. ${ }^{29}$ Pemerintah Provinsi dan kabupaten/kota dikepalai Gubernur dan Bupati/Walikota; anggota DPRD Provinsi dan kabupaten/kota dipilih melalui pemilu, sedangkan Gubernur dan Bupati/Walikota dipilih secara demokratis ${ }^{30}$.

Melihat desain pemerintahan daerah dalam konstitusi tersebut maka penulis berpandangan bahwa Undang-Undang Pemilu seyogyanya mengikuti desain yang diterapkan pada tingkat pusat tersebut. Ketika dalam ratio decidendi putusan Mahkamah Konstitusi nomor 14/PUU-XI/2013, berpandangan bahwa dalam penyelenggaraan Pilpres tahun 2004 dan tahun 2009 yang dilakukan setelah Pemilu Anggota Lembaga Perwakilan ditemukan fakta politik bahwa untuk mendapat dukungan demi keterpilihan sebagai Presiden dan dukungan DPR dalam penyelenggaraan pemerintahan, jika terpilih, calon Presiden terpaksa harus melakukan negosiasi dan tawar-menawar politik (bargaining politic) terlebih dahulu dengan partai politik yang berakibat sangat mempengaruhi jalannya roda pemerintahan dikemudian hari ${ }^{31}$. Berdasar pertimbangan tersebut maka menurut hemat penulis ketika pemilihan kepala daerah dilakukan tidak bersamaan dengan pemilihan lembaga perwakilan didaerah, maka ada potensi besar kepala daerah terpilih tidak memiliki dukungan mayoritas di parlemen daerah, dan bila hal tersebut terjadi maka akan melahirkan politik dagang sapi, dimana sang kepala daerah terpilih akan disudutkan oleh tekanan-tekanan politik jangka pendek yang tentu apabila tidak menuruti permintaan jangka pendek yang dimaksud, maka hal tersebut akan bermuara pada instabilitas pemerintahan di daerah.

\section{2) Isu Daerah tidak menjadi Preferensi Pemilih.}

Pada perhelatan pemilihan lembaga perwakilan di daerah, ada kecenderungan calon DPRD yang berlaga, hanya menduplikat isu-isu kampanye pusat, padahal para calon anggota dewan di daerah ini ketika terpilih mereka bekerja berdasarkan masalahmasalah yang ada di daerah, menjadi aneh ketika pada masa kampanye isu-isu daerah yang seyogyanya menjadi isu utama untuk meyakinkan pemilih menjadi tidak tersentuh oleh para calon anggota legislatif di daerah tersebut.

\footnotetext{
${ }^{28}$ Pasal 18 ayat (1) Undang-Undang Dasar Negara RI Tahun 1945.

${ }^{29}$ Pasal 18 ayat (3) Undang-Undang Dasar Negara RI Tahun 1945.

${ }^{30}$ Pasal 18 ayat (5) Undang-Undang Dasar Negara RI Tahun 1945.

${ }^{31}$ Ratio decidendi Putusan Mahkamah Konstitusi Nomor 14/PUU-XI/2013, hlm. 81.
} 
Penulis mengamati bahwa kampanye Pemilihan Presiden dan Wakil Presiden yang membawa isu-isu Nasional berhasil menghipnotis pemilih dan membuat pemilih di daerah yang akan menjatuhkan pilihannya pada calon lembaga legislatif di daerah, menjadi terbuai dan akhirnya lupa bahwa sesungguhnya isu-isu nasional tersebut belum tentu relevan dengan persoalan yang ada di daerah masing-masing yang nantinya hendak diamanahkan kepada pemimpin yang ada di daerah.

Pada titik tertentu fenomena teralihnya preferensi pemilih di daerah yang akan menjatuhkan pilihan pada lembaga parlemen di daerah kemudian tersedot perhatiannya kepusat bisa dipahami karena kuatnya sumber pendanaan serta kekuatan penguasaan media oleh para tim kampanye tingkat nasional sehingga tim kampanya pusat mampu mendominasi dan menggerus isu-isu daerah. Hal ini menjadi semakin parah dengan maraknya calon anggota lembaga parlemen di daerah yang ikut-ikutan dengan materi kampanye pusat, yang dalam beberapa kasus materi kampanye tersebut tidak relevan dengan isu-isu daerah dimana dia mencalonkan sebagai anggota dewan daerah.

\section{3) Koalisi di Daerah Bersifat Pragmatis.}

Pemilihan kepala daerah dan wakil kepala daerah dengan pemilihan anggota legislatif di daerah yang terpisah mendorong koalisi di daeah yang bersifat pragmatis, hal tersebut dikarenakan kemenangan dalam pemilihan kepala daerah dan wakil kepala daerah menjadi target tertinggi di atas target-target yang lain, sehingga karena target tersebut koalisi tidak terlalu memikirkan efektifitas pemerintahan paska kemenangan diraih.

Prediksi persoalan di atas terkonfirmasi dengan berjamurnya kepala daerah terpilih yang terjebak dengan kepentingan politik jangka pendek, sehingga sang kepala daerah tidak berfikir perihal akuntabilitas. Hipotesa tersebut dapat dilihat antara lain maraknya kasus-kasus tindak pidana korupsi di tingkat daerah.

Salah satu diantara sebab sang calon kepala daerah sebelum pemilihan dan bahkan setelah pemilihan mendapat tekanan-tekanan politik tertentu, tekanan pra pemilihan mulai dari mahar politik pada partai yang akan mengusungnya, kemudian biaya tim kampanye dari masing-masing partai dan sejenisnya, kemudian tekanan paska pemilihan adalah permintaan proyek tertentu, bisa juga permintaan untuk menempatkan orang tertentu dalam satuan kerja dalam pemerintahan daerah (SKPD), serta beberapa bentuk tekanan lainnya, yang kesemuanya mendorong sang kepala daerah mengalami situasi dilema karena merasa berhutang budi, dan akhirnya menuruti tekanan-tekanan tersebut. Pengalaman di lapangan menunjukkan bahwa persoalan korupsi yang menjerat kepala daerah bukan semata-mata faktor lemahnya moral dan lemahnya mental, karena tidak sedikit kepala daerah yang sebelumnya terkenal alim dan memiliki rekam jejak bersih, namun akhirnya terjerembab kedalam lembah nista korupsi. Berdasar hal demikian maka desain sistem yang bobrok didaerah turut menyumbang dan mengarahkan kepala daerah terjebak dalam politik transaksional tersebut.

Roda pemerintahan daerah sangat dipengaruhi dua kekuasaan besar yaitu kepala daerah dan DPRD, karena segala progam pemerintah daerah mutlak memerlukan biaya, yang dimana semua biaya progam pemerintah daerah tersebut harus dimasukkan dalam penganggaran di anggaran pendapatan belanja daerah (APBD), sementara pada sisi yang lain segala bentuk penganggaran yang diajukan oleh sang kepala daerah mutlak harus mendapat restu dari DPRD. Situasi itulah yang menyebabkan kebijakan sang kepala daerah dalam beberapa hal sering didikte oleh DPRD, belum lagi dalam kondisi kepala 
daerah mendapat dukungan minoritas di parlemen daerah, maka persoalan tersebut menjadi semakin runyam. Pengalaman sejarah terjeratnya Gubernur Jambi Zumi Zola adalah salah satu contoh kongkrit, dimana Gubernur Jambi tersebut melalui kroni-kroni terpaksa menyerahkan uang kepada anggota DPRD Jambi dalam rangka untuk mendapat persetujuan APBD yang diajukan oleh sang Gubernur Jambi tersebut.

\section{4) Pemilih Tidak Memiliki Kanal Untuk Evaluasi}

Pemilihan anggota Parlemen di tingkat pusat dan Pemilihan Anggota Parlemen di daerah dilaksanakan secara bersamaan dalam kurun waktu 5 (lima) tahun sekali, ketika musim kampanye di helat para calon wakil rakyat tersebut berlomba-lomba untuk menarik simpati pemilih dengan menawarkan janji-janji manis. Pada faktanya terdapat calon anggota legislaif terpilih yang mampu merealisasikan janji kampanyenya, akan tetapi tidak sedikit anggota dewan terpilih yang jauh panggang dari api. Dalam arti janjijanji semasa kampanye tidak ada satupun yang dilaksanakan, bahkan yang lebih parah adalah terdapat anggota dewan terpilih yang menjalankan progam yang apabila dicermati bertentangan dengan arah janji kampanyenya.

Pada situasi demikian maka, dengan model pemilu seperti sekarang maka pemilih tidak memiliki kanal untuk evaluasi, karena kanal evaluasi bagi pemilih hanya disediakan 5 (lima) tahun sekali. Oleh karenanya anggota dewan terpilih relatif tidak memiliki kontrol dari masyarakat, karena alat kontrol masyarakat yang paling ampuh adalah tidak memilihnya dalam pemilu berikutnya.

Daya kontrol pemilih terhadap anggota legislatif dan partai politik akan meningkat jika skema pelaksanaan pemilu anggota DPR dipisah dari pemilu DPRD. Misalnya pemilihan anggota DPR dilaksanakan tahun pertama, lalu pemilihan umum untuk DPRD dilakukan 30 (tiga puluh) bulan setelahnya, dengan skema tersebut, secara alamiah pemilih akan menggunakan pemilu DPRD sebagai alat untuk menjatuhkan hukuman atas kinerja hasil pemilu DPR, atau sebaliknya dimana ketika akan memilih angota DPR pemilih akan menjadikan kinerja DPRD hasil pemilu sebelumnya sebagai preferensi dalam menjatuhkan pilihan. Dengan model seperti demikian rakyat memiliki kanal dan juga alat kontrol bagi kinerja partai politik. Skema pemilihan DPR dan DPRD yang terpisah pula akan mendorong partai politik untuk menjalin hubungan secara intensif dengan pemilih demi memenangkan pemilu-pemilu berikutnya.

\section{5) Menyuburkan Opportunisme Politisi di Daerah.}

Pemilihan kepala daerah dan wakil kepala daerah yang dilakukan secara terpisah dengan anggota dewan perwakilan daerah akan melahirkan paham politik yang ingin menguasai semuanya, paham politik seperti demikan tidak hanya akan merusak sistem bekerjanya mesin pemerintahan daerah, akan tetapi juga akan membatasi ruang bagi kandidat lain yang sebenarnya memiliki rekam jejak baik serta memiliki integritas, terpaksa tersingkir karena tidak mendapat perahu untuk berlayar menuju pulau kandidasi sebagai calon kepala daerah. Dengan menerapkan sistem pemilihan kepala daerah dan anggota dewan di daerah secara bersamaan maka orang yang akan maju sebagai calon kepala daerah, hendaknya sudah mempersiapkan sedari awal menyangkut pencalonannya. Serta model seperti ini akan menutup celah bagi calon kepala daerah dadakan yang hanya karena situasi dan kondisi tertentu sehingga terpaksa dimajukan. 


\section{c. Titik Ekuilibrium Sistem Pemilihan dengan Sistem Pemerintahan}

Berdasarkan pada penjelasan diatas maka pemisahan antara pemilihan umum pada tingkat pusat (pemilihan Presiden dan wakil Presiden serta Pemilihan DPR dan DPD secara bersamaan) dengan pemilihan umum pada tingkat daerah (pemilihan kepala daerah dan wakil kepala daerah serta DPRD Provinsi dan Kabupaten/Kota) menjadi satu alternatif yang perlu dipertimbangkan sebagai upaya menguatkan bangunan sistem presidensial di pusat dan di daerah. Alternatif tersebut semakin menguat ketika dalam ratio decidendi putusan MK Nomor 55/XVII/2019 menyatakan bahwa pemilu serentak 5 (lima) kotak sebagaimana dikehendaki oleh UUD 1945 bukanlah satu-satunya gagasan yang berkembang dan diperdebatkan selama perubahan UUD 1945, sebab pengubah UUD 1945 tidak begitu mempersoalkan apakah penyelenggaraan pemilu DPR, DPD, Presiden dan wakil Presiden, dan anggota DPRD dilakukan secara serentak semuanya, serentak sebagian, digabungkan semua atau dipisah-pisah, sepanjang pilihan yang tersedia bermuara kepada penguatan sistem pemerintahan presidensial, maka pilihan pemilihan serentak yang demikian adalah tetap konstitusional ${ }^{32}$.

Pandangan MK dalam putusan Nomor 55/XVII/2019 seakan hendak mengatakan bahwa model pilihan pemilu serentak sebagaimana dipraktikkan dalam pemilu tahun 2019 yaitu pemilihan Presiden dan Wakil Presiden, kemudian dibarengkan dengan pemilihan anggota DPR, DPD dan DPRD Provinsi dan Kabupaten Kota bukanlah pilihan satusatunya yang bisa diambil oleh pembuat Undang-Undang, pandangan demikian terkonfirmasi kebenarannya, karena dalam ratio decidendi putusan MK menyatakan bahwa sebagai bagian dari penguatan sistem presidensial pemilu serentak dengan cara menyerentakkan pemilihan umum lembaga perwakilan (DPR, DPD, DPRD) dengan pemilihan umum Presiden dan Wakil Presiden masih terbuka kemungkinan ditinjau dan ditata kembali ${ }^{33}$. Berdasar pandangan MK tersebut maka sesungguhnya model pilihan pemilu pusat dan daerah dalam rangka memperkuat sistem Presidensial di pusat dan di daerah yang ditawarkan penulis tetaplah konstitusional dan mendapat legitimasi yang kuat secara hukum.

Teknis pelaksanaannya dapat dilakukan dengan menyelenggarakan pemilu tingkat pusat (Pemilihan Presiden dan Wakil Presiden bersamaan dengan pemilu anggota DPR dan DPD) secara bersamaan, kemudian 30 (tiga puluh) bulan setelah itu baru dilaksanakan pemilihan ditingkat daerah (pemilihan kepala daerah dan wakil kepala daerah bersamaan dengan pemilihan anggota DPRD Provinsi dan Kabupetn/Kota). Interval waktu 30 (tiga puluh) bulan diperlukan dalam rangka memberi waktu kepada pemilih untuk menilai apakah pemenang yang berlaga dalam pemilihan tingkat pusat berhasil merealisasi janji kampanyenya, dasar tersebut pemilih memiliki preferensi dalam memilih pada pemilu daerah, begitu juga preferensi pemilih dalam pemilu pusat berikutnya dapat mengacu pada realisasi janji kampanye yang menang pada pemilu daerah. Gagasan demikian dapat menjadi titik ekuilibrium dari sejumlah persoalan di daerah sebagai akibat sistem pemilihan dengan pilihan sistem pemerintahan Presidensial yang dipraktikkan di tingkat pusat.

Pada tingkat pusat, sudah terbukti melalui pemilu tahun 2019 dimana dengan pemilihan umum serentak antara Presiden dan Wakil Presiden dengan pemilihan umum anggota DPR terbentuknya pemerintahan yang stabil. Karena Presiden terpilih memiliki

\footnotetext{
${ }^{32}$ Putusan Mahkamah Konstitusi Nomor 55/XVII/2019, hlm. 317.

${ }^{33}$ Ibid.,Putusan MK...hlm. 323.
} 
dukungan mayoritas di DPR, fenomena ini oleh Burhanudin Muhtadi disebut coattail effect (efek ekor jas), dimana dalam kontek pemilu legislatif dan pemilu Presiden secara serentak, efek ekor jas biasanya turut menentukan ${ }^{34}$. Fenomena kemenangan Jokowi-JK dalam Pilpres 2014 menjadi bukti, dimana Partai Demokrasi Indonesia Perjuangan (PDI-P) menerima luberan suara dari para pemilih Jokowi-JK saat itu, Meskipun faktanya bahwa Jokowi didukung juga oleh parti-partai lain. Pun demikan dalam Pilpres 2019 PDI-P tampil sebagai the rulling party tidak lepas dari efek ekor jas karena mencalonkan kembali Jokowi sebagai petarung andalannya. Dengan fakta dukungan politik seperti sekarang, maka penulis berpandangan bahwa Jokowi-Makruf Amin seyogyanya akan lebih percaya diri dalam menahkodai kapal besar Republik Indonesia, serta dengan model koalisi seperti dalam pemilu serentak 2019, maka bangunan koalisi akan lebih kokoh sehingga Jokowi-Makruf tidak mudah didikte oleh kebijakan politik pragmatis dari Parlemen.

Berdasarkan pada fakta terkait efek ekor jas sebagaimana telah digambarkan diatas, maka pelaksanaan pemilihan kepala daerah (Gubernur Wakil Gubernur, Bupati Wakil Bupati, serta Walikota Wakil Walikota) yang dilakukan secara bersamaan dengan pemilihan anggota DPRD Provinsi dan Kabupaten/Kota, kemudian 30 (tiga puluh) bulan kemudian pemilihan Presiden dan Wakil Presiden dilakukan bersamaan dengan pemilihan DPR dan DPD menjadi penting untuk dilakukan karena pemilu serentak ditingkat pusat sudah terbukti menyuguhkan kondisi dimana bangunan antara kekuatan eksekutif dan legislatif pusat yang kongruen.

Gagasan pelaksanaan pemilu pusat (Presiden dan DPR, DPD) dan pemilu daerah (DPRD Provinsi dan Kabupaten/Kota) yang dilakukan secara terpisah apabila terwujud maka akan menjadi sarana evaluasi dan alat kontrol bagi pemilih terhadap peserta pemilu yang sedang berkompetisi, dalam artian apabila pemerintahan hasil pemilu serentak nasional memiliki prestasi dan kinerja baik, maka besar kemungkinan pemilihan akan menjatuhkan pilihan pada partai yang sama di tingkat daerah. Apabila terwujud yang demikian maka pada suatu titik akan menghasilkan sinergi dan efektifitas pemerintahan nasional dan daerah. Begitu juga sebaiknya apabila kinerja tidak baik maka rakyat tidak harus menunggu 5 (lima) tahun untuk memberikan hukuman dalam bentuk tidak memilih kembali, setidaknya tidak menjatuhkan pada partai yang sama.

Penulis meyakini apabila pemilihan kepala daerah dan legislatif didaerah dilakukan secara serentak maka pada tingkat eksekutif daerah dan legistatif daerah akan terbentuk pemerintahan kongruen, karena pemilih yang menjatuhkan pilihan kepada Gubernur, Bupati/Walikota dari partai politik tertentu akan memiliki kecenderungan untuk memilih anggota legislatif dari partai politik yang mendukung calon Gubernur Bupati/Walikota tersebut. Bila kepala daerah terpilih memiliki dukungan mayoritas di parlemen maka beberapa problematika di daerah seperti ketidak-harmonisan hubungan eksekutif dan legislatif di daerah, tergerusnya isu-isu daerah dalam kampanye, koalisi jangka pendek, penguasa yang minus kontrol dari pemilih, opportunisme politisi di daerah, dan sejumlah persolan lain di daerah dapat terminimalisir.

${ }^{34}$ Burhanudin Muhtadi, (2019), Populisme Politik Identitas dan Dinamika Electoral, Malang, Intrans Publishing, hlm. 196. 


\section{KESIMPULAN}

Dari pemaparan perihal menggagas titik ekuilibrium sistem pemilihan dengan sistem pemerintahan di atas maka dapat ditarik benang merah bahwa perlu dilakukan desain ulang perihal model sistem pemilihan kepala daerah dan wakil kepala daerah serta pemilihan anggota legislatif di daerah, dengan pilihan sistem presidensial yang telah dianut. Salah satu titik ekuilibrium yang dapat ditawarkan adalah dengan memisahan antara pemilihan umum pada tingkat pusat (pemilihan Presiden dan wakil Presiden serta Pemilihan DPR dan DPD secara bersamaan) dengan pemilihan umum pada tingkat daerah (pemilihan kepala daerah dan wakil kepala daerah serta DPRD Provinsi dan Kabupaten/Kota).

Melalui desain tersebut diharapkan terbangun kekuatan yang kongruen antara eksekutif daerah dan legistatif daerah. Penulis meyakini apabila kepala daerah terpilih memiliki dukungan mayoritas di parlemen daerah maka kepala derah dapat fokus menjalankan roda pemerintahan di daerah dan tidak mudah didikte oleh parlemen daerah, serta dengan bangunan kekuatan kongruen antara eksekutif dan legislatif daerah maka beberapa problematika di daerah seperti instabilitas pemerintahan daerah, tergerusnya isu-isu daerah dalam kampanye, koalisi jangka pendek, penguasa yang minus kontrol dari pemilih, serta sikap opportunisme polisi di daerah dapat terselesaikan secara baik.

\section{Daftar Pustaka}

Burhanudin Muhtadi, (2019), Populisme Politik Identitas dan Dinamika Electoral, Malang, Intrans Publishing.

Denny Indrayana, (2007), Amandemen UUD 1945 Antara Mitos dan Pembongkaran, Bandung, Mizan.

Jimly Asshidiqie, (2007), Pokok-Pokok Hukum Tata Negara Indonesia Paska Reformasi, Jakarta, PT. Buana Ilmu Populer.

Jimly Asshidiqie, (2015), Penguatan Sistem Pemerintahan dan Peradilan, Jakarta, Sinar Grafika.

Moh. Mahfud MD, (1993), Dasar dan Struktur Ketatanegaraan Indonesia, Yogyakarta, Universitas Islam Indonesia Press.

Pan Muhammad Faiz, (2019), Amandemen Konstitusi Komparasi Negara Kesatuan dan Negara Federal, Depok, Rajawali Pers.

PM. Marzuki, (2010), Penelitian Hukum, Jakarta, Kencana Prenada Media Group.

Saldi Isra, (2017), Pemilu dan Pemulihan Daulat Rakyat, Jakarta, Themis Publishing.

Saldi Isra, Fahmi Khairul, (2019), Pemilihan Umum Demokratis, Depok, Rajawali Press.

Soerjono Soekanto\&Sri Mamudji,(2011),Penelitian Hukum Normatif,Jakarta, Rajawali Pers.

Teguh Prasetyo, (2018), Filsafat Pemilu, Bandung, Penerbit Nusa Media.

Very Junaidi dkk. (2019), Membaca 16 tahun Mahkamah Konstitusi data uji materi undang-undang terhadap UUD 1945 (2003-2019), Jakarta, Yayasan Konstitusi Demokrasi Inisiatif. 
Samsudin Haris, Peneliti dari Lembaga Ilmu Pengetahuan Indonesia (LIPI), Materi disampaikan dalam rapat dengar pendapat umum dengan panitia khusus (Pansus) Rancangan Undang-Undang tentang Penyelenggaraan Pemilu, masa persidangan III, tertanggal 18 Januari 2017

\section{Peraturan PerUndang-Undangan.}

Undang-Undang Dasar Negara RI Tahun 1945.

Undang-Undang Nomor 7 Tahun 2017 tentang Pemilihan Umum.

Undang Nomor 8 tahun 2015 tentang Perubahan atas Undang-Undang Nomor 1 tahun 2015 tentang Penetapan Peraturan Pemerintah Pengganti Undang-Undang Nomor 1 tahun 2014 tentang Pemilihan Gubernur, Bupati, dan Walikota menjadi UndangUndang.

Undang-Undang Nomor 23 tahun 2014 tentang Pemerintahan Daerah.

\section{Putusan Mahkamah Konstitusi.}

Putusan Mahkamah Konstitusi Nomor 55/XVII/2019

Putusan Mahkamah Konstitusi Nomor 14/PUU-XI/2013. 